\title{
Faktor-faktor yang berhubungan dengan kejadian GAKY pada anak sekolah dasar di pinggiran pantai Kota Palu Provinsi Sulawesi Tengah
}

\author{
Normawaty Patuti', Toto Sudargo ${ }^{2}$, Deddy Nur Wachid ${ }^{3}$
}

\begin{abstract}
Background: lodine deficiency disorder (IDD) is one of serious health problems considering that it has great impact to survival and quality of human resources. The core problem of IDD is initially caused by lack of iodine in water and soil, then heightened by goitrogenic substances in the food consumed, more pollutants as side effects of industrial waste, the blocking agent which naturally exists in water and soil in the surrounding dwelling places.

Objective: The study aimed to identify factors affecting the prevalence of IDD among elementary school children at coastal region.

Method: The study was analytic observational with cross sectional design. Population and samples of the study were elementary school children of grade 4-6 proportionally chosen that fulfilled inclusion criteria. Variables observed were consumption pattern, environment (drinking water plumbum), and children's hemoglobin. Data analysis used computer software at significance level $p<0.05$ and confidence interval 95\% and estimation of risk level (Odds Ratio) with chi square. The result of analysis was presented in frequency distribution table and percentage. Analysis of food nutrient was done with recall 24 hours, dietary history. Examination was made to thyroid gland palpation and hemoglobin using cyanomethemoglobin and drinking water plumbum using Atomic Absorption Spectrophotometer.

Result: The result of independent and dependent statistical test showed that there was significant effect of consumption pattern of protein source to the prevalence of IDD $(p<0.05)$, iron source to the prevalence of IDD $(p<0.05)$, zinc source to the prevalence of IDD ( $p<0.05)$, iodine source to the prevalence of IDD $(p<0.05)$ and hemoglobin source to the prevalence of IDD ( $p<0.05)$. Meanwhile, there was no effect of source goitrogenic (thiocyanate) to the prevalence of IDD $(p>0.05)$, drinking water plumbum level to the prevalence of IDD ( $p>0.05)$.

Conclusion: There was significant effect of consumption pattern of protein, iodine and hemoglobin level to the prevalence of IDD among elementary school children at coastal region of Palu Municipality. There was no effect of drinking water plumbum level to the prevalence of IDD among elementary school children at coastal region of Palu Municipality.
\end{abstract}

KEY WORDS iodine deficiency disorder, elementary school children, coastal region

\section{PENDAHULUAN}

Rendahnya status gizi masyarakat yang dialami oleh banyak negara berkembang termasuk Indonesia merupakan salah satu indikator derajat kesehatan masyarakat dan kualitas sumber daya manusia suatu bangsa. Masalah Gangguan Akibat Kekurangan Yodium (GAKY) merupakan masalah serius karena diperkirakan pada saat ini terdapat sekitar 42 juta penduduk Indonesia tinggal di daerah yang lingkungannya miskin yodium (1).

GAKY di Indonesia merupakan salah satu masalah kesehatan masyarakat yang serius mengingat dampaknya sangat besar terhadap kelangsungan hidup dan kualitas sumber daya manusia. Selain berupa pembesaran kelenjar gondok dan hipotiroid, kekurangan yodium jika terjadi pada wanita hamil mempunyai risiko terjadinya abortus, lahir mati, sampai cacat bawaan pada bayi yang lahir berupa gangguan perkembangan syaraf, mental dan fisik yang disebut kretin. Semua gangguan ini dapat berakibat pada rendahnya prestasi belajar anak usia sekolah, rendahnya produktifitas kerja pada orang dewasa serta timbulnya berbagai permasalahan sosial ekonomi masyarakat yang dapat menghambat pembangunan (2).
Kekurangan yodium dalam makanan sehari-hari dan berlangsung lama akan menganggu fungsi kelenjar tiroid, bila sintesis hormon tiroid berkurang kadar tiroksin $\left(T_{4}\right)$ dan $\mathrm{T}_{3}$ di dalam darah memicu sekresi Thyroid Stimulating Hormone (TSH) merangsang kelenjar tiroid untuk menyerap lebih banyak yodium. Hal ini menyebabkan kelenjar tiroid bekerja lebih giat, sehingga secara perlahan kelenjar ini membesar (hyperplasia) dan disebut gondok (3).

Beberapa keadaan yang sering dihubungkan dengan penyebab gondok endemik yaitu kekurangan yodium, faktor goitrogen, faktor excess yodium, trace elements, genetik serta faktor gizi pada umumnya (4). Defisiensi yodium memang agak berbeda masalahnya dengan kekurangan gizi lainnya. Permasalahan utama adalah lingkungan yang kurang akan yodium atau karena adanya gangguan

\footnotetext{
Dinas Kesehatan Singgani, Palu, Sulawesi Tengah, e-mail: normapatuti@yahoo.co.id

2 Magister Gizi Kesehatan UGM, JI Farmako, Sekip Utara, Yogyakarta 55281,e-mail: totosud@indosat.net.id

3 Bagian Penyakit Dalam, Fakultas Kedokteran, Universitas Gajah Mada
} 
lain yaitu zat goitrogenik yang dapat menyebabkan pembesaran kelenjar tiroid (5).

Defisiensi yodium merupakan penyebab hipotiroidisme yang lebih sering ditemukan di negara-negara berkembang. Selanjutnya dalam sumber yang sama dikatakan bahwa defisiensi besi pada seseorang dapat mengganggu kemampuan kognitif sepanjang hidupnya. Anak-anak yang terhambat perkembangan psikomotornya, ketika mencapai usia sekolah, kemampuan kognitifnya akan terganggu, yaitu dalam tes bahasa, ketrampilan, dan koordinasi atau sama dengan penurunan IQ sebesar 5-19 poin (6). Penelitian lain menyatakan bahwa keadaan hipotiroidisme turut berperan dalam terjadinya anemia defisiensi besi di mana terjadi gangguan sintesis hemoglobin akibat defisiensi hormon tiroksin serta kegagalan usus untuk mengabsorpsi besi (7).

Akar permasalahan GAKY yang semula disebabkan miskinnya unsur yodium dalam air dan tanah, kemudian diperberat dengan adanya zat goitrogenik dalam makanan yang kita konsumsi, makin banyak polutan sebagai dampak samping dari modernisasi atau dari limbah industri, adanya blocking agent yang secara alami terdapat dalam air dan tanah di lingkungan tempat tinggal, dan ikut berperan digunakannya alat kontrasepsi hormonal dalam menjarangkan kelahiran, menyebabkan masalah GAKY merupakan masalah gizi laten yang tak kunjung hilang (8).

Data prevalensi penderita GAKY hasil survei nasional gondok endemik 1980-1982 diperkirakan di Indonesia telah terjadi defisit tingkat kecerdasan sebesar 140 juta IQ-points. Hasil survei pemetaan tahun 1998 menunjukkan terjadinya penurunan tajam angka prevalensi GAKY, yaitu dari $27,7 \%$ pada tahun 1992 menjadi $9,8 \%$. Hal ini memberikan gambaran adanya keberhasilan program penanggulangan GAKY secara nasional.

Namun demikian, bila dilihat berdasarkan kecamatan, masih banyak penduduk yang tinggal di daerah endemik. Selain itu, penurunan angka Total Goiter Rate (TGR) atau lebih dikenal angka gondok total tersebut belum diikuti oleh tingkat konsumsi garam beryodium, yang pada tahun 1998 masih sebesar 65,2\% ${ }^{9}$. Hasil survei pemetaaan tahun 2003 menunjukkan bahwa prevalensi TGR masih cukup besar yaitu sekitar $11,1 \%$, namun konsumsi garam beryodium telah mengalami peningkatan menjadi $73,26 \%$ (9).

Prevalensi GAKY di Propinsi Sulawesi Tengah selama kurun waktu 5 tahun terakhir telah mengalami penurunan sebesar $34 \%$ dari keadaan sebelumnya yaitu $16,5 \%$ pada tahun 1998 menjadi $10,8 \%$ pada tahun 2003. Walaupun secara provinsi telah terjadi penurunan prevalensi GAKY, namun penurunan prevalensi ini belum merata untuk semua kabupaten (10).

Prevalensi GAKY di Kota Palu berdasarkan hasil survei pada tahun 1998 TGR sebesar 14,25\% dengan rincian sebagai berikut : Kecamatan Palu Utara 23,66\% (endemis sedang), Kecamatan Palu Timur 2,33\% (non endemis), Kecamatan Palu Selatan 19,33\% (endemis ringan), dan
Kecamatan Palu Barat 11,68\% (endemis ringan). Tahun 2003 dilakukan survei GAKY hanya di Kecamatan Palu Barat yang prevalensi TGR mencapai 9,0\% (11).

Penyakit GAKY di Kecamatan Palu Utara menempati urutan tertinggi kasusnya dibandingkan dengan 3 kecamatan lainnya yang ada di Kota Palu pada tahun 1998. Dan sejak itu telah dilakukan penanggulangan GAKY dengan pemberian kapsul Yodiol pada wanita usia subur, ibu hamil, serta ibu menyusui dan sosialisasi pemakaian garam beryodium, namun hingga saat ini belum dilaksanakan survei GAKY kembali.

Kecamatan Palu Utara daerahnya terletak di pinggiran pantai, namun daerah tersebut termasuk kategori endemis sedang. Berdasarkan permasalahan tersebut, maka perlu dilakukan penelitian tentang faktor-faktor yang mempengaruhi kejadian GAKY pada masyarakat di pinggiran pantai Kota Palu khususnya di Kecamatan Palu Utara dengan cara melaksanakan survei GAKY kembali, karena pada tahun 2003 dilaksanakan survei GAKY hanya di Kecamatan Palu Barat.

Berdasarkan uraian di atas, rumusan masalah pada penelitian ini adalah apakah faktor pola makan, faktor lingkungan dan faktor hemoglobin berhubungan dengan kejadian GAKY pada anak sekolah dasar di pinggiran pantai Kota Palu. Tujuan penelitian ini adalah untuk mengetahui prevalensi dan faktor-faktor (pola makan, lingkungan, kadar hemoglobin) yang berhubungan dengan kejadian GAKY pada anak sekolah dasar di pinggiran pantai Kota Palu Provinsi Sulawesi Tengah.

\section{BAHAN DAN METODE}

Jenis penelitian ini adalah penelitian observasional analitik dengan rancangan studi potong lintang (cross sectional) yang bertujuan untuk mengetahui prevalensi GAKY pada anak sekolah dan faktor-faktor yang berhubungan dengan kejadian GAKY pada anak sekolah dasar di pinggiran pantai.

Tempat penelitian di Kota Palu Provinsi Sulawesi Tengah, yang dilaksanakan selama 3 (tiga) bulan dari bulan Oktober sampai Desember 2007. Populasi penelitian ini adalah seluruh anak sekolah dasar kelas 4-6 yang berada di wilayah Kecamatan Palu Utara Kota Palu tahun ajaran 2007-2008. Jumlah populasi sebanyak 2195 orang. Subyek penelitian dipilih di antara populasi penelitian anak sekolah dasar di pinggiran pantai kelas 4-6 yang memenuhi kriteria di wilayah Kecamatan Palu Utara dengan kriteria inklusi : anak kelas 4-6 tahun ajaran 2007-2008, tinggal di daerah penelitian kurang lebih 6 bulan dan bersedia menjadi subjek penelitian dengan menandatangani informed consent serta kriteria eksklusi adalah anak pindahan dari luar kecamatan lokasi penelitian dan anak kelas 4-6 SD tahun ajaran 2007-2008 yang berpenyakit kronis. 
Tabel 1. Prevalensi GAKY Kecamatan Palu Utara berdasarkan TGR Anak Sekolah

\begin{tabular}{lcccccl}
\hline \multirow{2}{*}{ Kelurahan } & \multirow{2}{*}{ Jumlah sampel } & \multicolumn{3}{c}{ Derajat } & \multirow{2}{*}{ TGR \% } & \multirow{2}{*}{ Endemisitas } \\
\cline { 3 - 5 } & & $\mathbf{0}$ & $\mathbf{1}$ & $\mathbf{2}$ & & \\
\hline Mamboro & 99 & 71 & 28 & 0 & 28,2 & Endemis sedang \\
Taipa & 134 & 64 & 68 & 2 & 52,2 & Endemis berat \\
Baiya & 86 & 68 & 18 & 0 & 20,9 & Endemis sedang \\
Pantoloan & 72 & 55 & 17 & 0 & 23,6 & Endemis sedang \\
Panau & 98 & 70 & 28 & 0 & 28,5 & Endemis sedang \\
Kayumalue Ngapa & 177 & 130 & 43 & 4 & 26,5 & Endemis sedang \\
Kayumalue Pajeko & 102 & 82 & 20 & 0 & 19,6 & Endemis ringan \\
Lambara & 103 & 77 & 25 & 1 & 25,2 & Endemis sedang \\
Total Kecamatan & 871 & 615 & 247 & 9 & 28,3 & Endemis sedang \\
\hline
\end{tabular}

Besar sampel sebanyak 92 orang, yang selanjutnya dikatakan subjek penelitian. Jumlah besar sampel dihitung dengan menggunakan rumus pendugaan $\mathrm{P}$ dalam jarak "d" persen (12) dengan nilai NZ (jumlah populasi dan nilai standar distribusi normal yang dipilih sebesar $1,96^{2}$, $\mathrm{p}$ (perkiraan variable yang dipilih) sebesar 0,5 , derajat ketelitian adalah $0,1^{2}$ dan $\mathrm{N}$ (jumlah populasi sebesar 1,962, sehingga diperoleh sebanyak 92 orang subjek penelitian.

Variabel terikat yaitu status GAKY dan variabel bebas yaitu faktor pola makan, faktor lingkungan (kadar plumbum air minum) dan kadar hemoglobin. Instrumen penelitian adalah buku register siswa dan kuesioner dietary history dan recall 24 jam yang dianalisis dengan nutri survey, pedoman palpasi kelenjar tiroid dan botol untuk pemeriksaan plumbum $(\mathrm{Pb})$ air minum yang dianalisis dengan menggunakan metode AAS (Atomic Absorption Spectrofotometer) serta pemeriksaan kadar $\mathrm{Hb}$ menggunakan metode Cyanmethemoglobin. Analisis dengan menggunakan software komputer dengan tingkat kemaknaan $\mathrm{p}<0,05$ dan tingkat kepercayaan 95\% serta mengestimasi besarnya risiko (Odds Ratio) dengan uji Chi Square. Penyajian hasil analisis dalam bentuk tabel distribusi frekuensi dan persentase.

\section{HASIL DAN BAHASAN}

\section{Karakteristik subjek penelitian Analisis univariat}

Survei ulang prevalensi gondok dilakukan pada 10 (sepuluh) sekolah dasar yang ada di kecamatan endemik. Survei ini dilakukan selama 1 (satu) bulan, yang menjadi enumerator dalam penelitian ini adalah petugas gizi yang terlatih dibantu oleh peneliti. Hasil survei prevalensi GAKY di Kecamatan Palu Utara berdasarkan TGR anak sekolah seperti tersaji pada Tabel 1.

Pada Tabel 1, terlihat bahwa prevalensi GAKY di Kecamatan Palu Utara masih termasuk daerah yang endemis sedang (TGR 28,3\%). Hasil survei saat ini bila dibandingkan dengan tahun 1998 terjadi peningkatan 4,7\%. Peneliti tidak bisa membandingkan tingkat endemisitas per kelurahan dengan hasil survei tahun 1998, hal ini disebabkan karena adanya perubahan status wilayah Kota administratif Palu menjadi Kota Palu, sehingga terjadi pemekaran kelurahan.

Subjek dalam penelitian ini adalah anak sekolah dasar (kelas 4, 5 dan 6) yang masuk kriteria inklusi berjumlah 92 orang dengan sebaran jenis kelamin subjek yang sama, yaitu perempuan dan laki-laki berjumlah 46 orang (50\%). Pendidikan orang tua terbanyak tamat sekolah lanjutan pertama (SLTP) yaitu 34 orang $(37,0 \%)$. Pekerjaan orang tua, terbanyak adalah nelayan yaitu 31 orang $(33,7 \%)$. Sumber air bersih yang digunakan terbanyak yaitu sumur tanah 57 buah $(72,8 \%)$. Untuk lebih jelasnya disajikan pada Tabel 2.

\section{Pola makan subjek penelitian berdasarkan asupan protein, besi, zink, yodium dan zat goitrogenik (tiosianat)}

Jumlah asupan zat gizi subjek berdasarkan wawancara recall 24 jam dibagi 2 (dua) kriteria yaitu baik ( $\geq 80 \%$ AKG) dan kurang $(<80 \% \mathrm{AKG})$. Untuk asupan protein baik yaitu 38 subjek (41,3\%), asupan besi baik 75 subjek $(81,5 \%)$, asupan zink baik yaitu 71 subjek $(77,2 \%)$ dan asupan yodium baik yaitu 63 subjek $(68,5 \%)$. Untuk lebih jelasnya disajikan pada Tabel 3.

Jumlah asupan zat goitrogenik (tiosianat) berdasarkan wawancara recall 24 jam dibagi 2 (dua) kriteria yaitu tinggi bila asupan tiosianat $\geq 10 \mathrm{mg} / \mathrm{hari}$ dan rendah bila asupan tiosianat $<10 \mathrm{mg} /$ hari. Untuk asupan tiosianat tinggi sebanyak 48 subjek $(52,2 \%)$ dan asupan tiosianat rendah sebanyak 44 subjek penelitian $(47,8 \%)$.

Untuk jumlah asupan maksimum protein $43,2 \mathrm{gram} /$ hari, besi $14,1 \mathrm{mg} /$ hari, zink $11,2 \mathrm{mg} /$ hari, yodium 115,6 $\mu \mathrm{g} /$ hari dan tiosianat $12,2 \mathrm{mg} / \mathrm{hari}$. Untuk lebih jelasnya disajikan pada Tabel 4.

Berdasarkan Tabel 4, apabila dibandingkan dengan rata-rata asupan zat gizi AKG individu untuk protein 49,6 gram/hari, besi $15,3 \mathrm{mg} / \mathrm{hari}$, zink $12,9 \mathrm{mg} / \mathrm{hari}$ dan yodium $120 \mu \mathrm{g} / \mathrm{hari}$ ternyata semua asupan zat gizi subjek masih di bawah angka kecukupan. Untuk asupan tiosianat subjek masih dalam batas normal yaitu $9,81 \mathrm{mg} / \mathrm{hari}$. 
Tabel 2. Distribusi karakteristik subjek penelitian

\begin{tabular}{|c|c|c|}
\hline \multirow{2}{*}{ Karakteristik subjek } & \multicolumn{2}{|c|}{ Jumlah } \\
\hline & $\mathbf{n}$ & $\%$ \\
\hline \multicolumn{3}{|l|}{ Umur } \\
\hline 9 Tahun & 19 & 20,6 \\
\hline $10-12$ Tahun & 71 & 77,2 \\
\hline 13 Tahun & 3 & 2,2 \\
\hline \multicolumn{3}{|l|}{ Jenis kelamin } \\
\hline Laki-laki & 46 & 50,0 \\
\hline Perempuan & 46 & 50,0 \\
\hline Jumlah & 92 & 100 \\
\hline \multicolumn{3}{|l|}{ Pendidikan orang tua } \\
\hline SD & 9 & 9,8 \\
\hline SLTP & 34 & 37,0 \\
\hline SLTA & 32 & 34,7 \\
\hline Akademi & 12 & 13,1 \\
\hline Sarjana S1,S2 & 5 & 5,4 \\
\hline \multicolumn{3}{|l|}{ Pekerjaan orang tua } \\
\hline Buruh & 29 & 31,52 \\
\hline Dagang /Jasa & 5 & 5,43 \\
\hline Petani & 8 & 8,7 \\
\hline PNS / ABRI & 13 & 14,13 \\
\hline Pegawai swasta & 6 & 6,6 \\
\hline Nelayan & 31 & 33,7 \\
\hline \multicolumn{3}{|l|}{ Sumber air } \\
\hline Sumur Tanah & 57 & 72,8 \\
\hline Mata Air & 8 & 8,7 \\
\hline PAM & 17 & 18,5 \\
\hline Jumlah & 92 & 100 \\
\hline
\end{tabular}

Tabel 3. Distribusi pola makan subjek penelitian berdasarkan asupan, protein, besi, zink dan yodium

\begin{tabular}{|c|c|c|c|c|c|c|}
\hline \multirow{3}{*}{ Zat Gizi } & \multicolumn{4}{|c|}{ Asupan } & \multicolumn{2}{|c|}{ Jumlah } \\
\hline & \multicolumn{2}{|c|}{$\begin{array}{c}\text { Baik } \\
(\geq 80 \% A K G)\end{array}$} & \multicolumn{2}{|c|}{ Kurang (<80\%AKG) } & \multirow[t]{2}{*}{$\mathbf{n}$} & \multirow[t]{2}{*}{$\%$} \\
\hline & $\mathbf{n}$ & $\%$ & $\mathbf{n}$ & $\%$ & & \\
\hline Protein & 38 & 41,3 & 54 & 58,7 & 92 & 100 \\
\hline Besi & 75 & 81,5 & 17 & 18,5 & 92 & 100 \\
\hline Zink & 71 & 77,2 & 21 & 22,8 & 92 & 100 \\
\hline Yodium & 63 & 68,5 & 29 & 31,5 & 92 & 100 \\
\hline
\end{tabular}

Tabel 4. Distribusi asupan subjek penelitian berdasarkan jumlah minimum, maksimum dan rata-rata

\begin{tabular}{lccc}
\hline \multirow{2}{*}{ Asupan } & \multicolumn{3}{c}{ Jumlah } \\
\cline { 2 - 4 } & Minimum & Maksimum & Rata-rata \\
\hline Protein (g/hari) & 21 & 65 & 43,2 \\
Besi (mg/hari) & 6 & 29 & 14,1 \\
Zink (mg/hari) & 3,9 & 19,4 & 11,2 \\
Yodium $(\mu \mathrm{g} / \mathrm{hari})$ & 61,6 & 214,4 & 115,6 \\
Tiosianat $(\mathrm{mg} / \mathrm{hari})$ & 7,76 & 12,2 & 9,81 \\
\hline
\end{tabular}




\section{Status plumbum $(\mathrm{Pb})$ air}

Hasil pengukuran plumbum air yang dianalisis dengan menggunakan alat AAS (Atomic Absorption Spectrofotometer) dari 27 sampel yang diambil secara acak dari air minum yang bersumber dari perusahaan air minum (PAM), DAP, sumur pompa tangan, sumur gali, mata air, didapatkan hasil yang memenuhi syarat hanya 2 sampel $(7,4 \%)$, yang selengkapnya disajikan pada Tabel 5.

Tabel 5. Distribusi frekuensi berdasarkan status plumbum air minum

\begin{tabular}{lcc}
\hline \multicolumn{1}{c}{ Status plumbum (Pb) } & $\begin{array}{c}\text { Frekuensi } \\
\text { (n) }\end{array}$ & $\begin{array}{c}\text { Persentase } \\
(\%)\end{array}$ \\
\hline Memenuhi Syarat $(\leq 0,01 \mathrm{mg} / \mathrm{L})$ & 2 & 7,4 \\
$\begin{array}{l}\text { Tidak memenuhi Syarat } \\
(>0,01 \mathrm{mg} / \mathrm{L})\end{array}$ & 25 & 92,6 \\
Jumlah & 27 & 100 \\
\hline
\end{tabular}

\section{Kadar hemoglobin}

Hasil pengukuran kadar hemoglobin $(\mathrm{Hb})$ dengan menggunakan metode cyanmethaemoglobin diperoleh sebagian besar 65 subjek $(70,7 \%)$ dengan kadar hemoglobin $\geq 12 \mathrm{gr} / \mathrm{dl}$. Untuk lebih jelas hasilnya disajikan pada Tabel 6.

Tabel 6. Distribusi frekuensi subjek berdasarkan kadar hemoglobin

\begin{tabular}{lcc}
\hline \multicolumn{1}{c}{ Kadar $\mathbf{H b}$} & $\begin{array}{c}\text { Frekuensi } \\
\text { (n) }\end{array}$ & $\begin{array}{c}\text { Persentase } \\
(\%)\end{array}$ \\
\hline Tidak Anemia $(\mathrm{Hb} \geq 12 \mathrm{gr} / \mathrm{dl})$ & 65 & 70,7 \\
Anemia $(\mathrm{Hb}<12 \mathrm{gr} / \mathrm{dl})$ & 27 & 29,3 \\
Jumlah & 92 & 100 \\
\hline
\end{tabular}

\section{Status GAKY}

Berdasarkan hasil pemeriksaan palpasi pada 92 subjek didapatkan 61 subjek $(66,3 \%)$ mengalami pembesaran kelenjar tiroid. Untuk jelasnya disajikan pada Tabel 7.

Tabel 7. Distribusi frekuensi subjek berdasarkan Status GAKY

\begin{tabular}{lcc}
\hline \multicolumn{1}{c}{ Status GAKY } & $\begin{array}{c}\text { Frekuensi } \\
\text { (n) }\end{array}$ & $\begin{array}{c}\text { Persentase } \\
(\%)\end{array}$ \\
\hline $\begin{array}{l}\text { Mengalami Pembesaran } \\
\text { Kelenjar Tiroid }\end{array}$ & 61 & 66,3 \\
$\begin{array}{l}\text { Tidak Mengalami Pembesaran } \\
\text { Kelenjar Tiroid }\end{array}$ & 31 & 33,7 \\
Jumlah & 92 & 100 \\
\hline
\end{tabular}

\section{Analisis Bivariat}

\section{Pengaruh pola makan dengan status GAKY}

Pada Tabel 8, pola makan subjek dengan asupan protein baik dengan status GAKY sebanyak 11 subjek (Pola 11,9\%) dan asupan protein kurang dengan status tidak GAKY sebanyak 4 subjek (4,3\%). Asupan besi baik dengan status GAKY sebanyak 46 subjek $(50,0)$ dan asupan besi kurang dengan status tidak GAKY sebanyak 2 subjek (2,2\%). Asupan zink baik dengan status GAKY sebanyak 43 subjek $(46,7 \%)$ dan asupan zink kurang dengan status tidak GAKY sebanyak 3 subjek (3,3\%). Asupan zat yodium baik dengan status GAKY sebanyak 33 subjek $(35,9 \%)$ dan asupan zat yodium kurang dengan status tidak GAKY sebanyak 1 subjek $(1,1 \%)$.

Hasil uji Fisher's exact menunjukkan ada hubungan yang signifikan antara pola makan sumber protein $(p=0,000)$, dengan kejadian GAKY (nilai $p<$ nilai $\alpha=0,05$ ). Nilai OR untuk pola makan sumber protein dengan kejadian GAKY sebesar 30,628 , hal ini menunjukkan bahwa subjek yang memiliki pola makan sumber protein kategori kurang mempunyai peluang menderita GAKY 30,6 kali dibandingkan dengan subjek yang tidak menderita GAKY.

Hasil uji Fisher's exact menunjukkan ada hubungan yang signifikan antara pola makan sumber besi $(p=0,028)$, dengan kejadian GAKY (nilai $p<$ nilai $\alpha=0,05$ ). Nilai OR untuk pola makan sumber besi dengan kejadian GAKY sebesar 4,728, hal ini menunjukkan bahwa subjek yang memiliki besi kurang mempunyai peluang menderita GAKY 4,7 kali dibandingkan dengan subjek yang tidak menderita GAKY.

Hasil uji Fisher's exact menunjukkan ada hubungan yang signifikan antara pola makan sumber zink $(p=0,026)$, dengan kejadian GAKY (nilai $p<$ nilai $\alpha=0,05$ ). Nilai OR untuk pola makan sumber zink dengan kejadian GAKY sebesar 3,907, hal ini menunjukkan bahwa subjek yang memiliki pola makan sumber zink kurang mempunyai peluang menderita GAKY 3,9 kali dibandingkan dengan subjek tidak menderita GAKY.

Hasil uji Fisher's exact menunjukkan ada hubungan yang signifikan antara pola makan sumber yodium $(p=0,000)$ dengan kejadian GAKY (nilai $p<$ nilai $\alpha=0,05$ ). Nilai OR untuk pola makan sumber yodium dengan kejadian GAKY sebesar 25,4, hal ini menunjukkan bahwa subjek yang memiliki pola makan sumber yodium kurang mempunyai peluang menderita GAKY 25,4 kali dibandingkan dengan subjek yang tidak menderita GAKY.

Hasil uji Fisher's exact menunjukkan tidak ada hubungan yang signifikan antara pola makan sumber 
Tabel 8. Hubungan pola makan berdasarkan asupan zat gizi dengan status GAKY

\begin{tabular}{|c|c|c|c|c|c|c|c|c|}
\hline \multirow{3}{*}{ Asupan } & \multicolumn{4}{|c|}{ Status GAKY } & \multirow{2}{*}{\multicolumn{2}{|c|}{ Jumlah }} & \multirow{3}{*}{ OR } & \multirow{3}{*}{$\mathbf{p}$} \\
\hline & \multicolumn{2}{|c|}{ GAKY } & \multicolumn{2}{|c|}{ Tidak GAKY } & & & & \\
\hline & $\mathrm{n}$ & $\%$ & $\mathrm{n}$ & $\%$ & $\mathbf{n}$ & $\%$ & & \\
\hline \multicolumn{9}{|l|}{ Protein } \\
\hline Baik & 11 & 11,9 & 27 & 29,4 & 38 & 41,3 & 30,682 & 0,000 * \\
\hline Kurang & 50 & 54,4 & 4 & 4,3 & 54 & 58,7 & & \\
\hline \multicolumn{9}{|l|}{ Besi } \\
\hline Baik & 46 & 50,0 & 29 & 31,5 & 75 & 81,6 & 4,728 & $0,028^{*}$ \\
\hline Kurang & 15 & 16,3 & 2 & 2,2 & 17 & 18,4 & & \\
\hline \multicolumn{9}{|l|}{ Zink } \\
\hline Baik & 43 & 46,7 & 28 & 30,4 & 71 & 77,2 & 3,907 & $0,026^{*}$ \\
\hline Kurang & 18 & 19,6 & 3 & 3,3 & 21 & 22,8 & & \\
\hline \multicolumn{9}{|l|}{ Yodium } \\
\hline Baik & 33 & 35,9 & 30 & 32,6 & 63 & 68,5 & 25,4 & $0,000^{*}$ \\
\hline Kurang & 28 & 30,4 & 1 & 1,1 & 29 & 31,5 & & \\
\hline \multicolumn{9}{|l|}{ Tiosianat } \\
\hline Rendah & 25 & 27,2 & 19 & 20,7 & 44 & 47,8 & 2,28 & 0,052 \\
\hline Tinggi & 36 & 39,1 & 12 & 13,0 & 48 & 52,2 & & \\
\hline Jumlah & 61 & 66,3 & 31 & 33,7 & 92 & 100 & & \\
\hline
\end{tabular}

Keterangan: * = signifikan (Fisher exact)

tiosianat $(p=0,052)$ dengan kejadian GAKY (nilai $p$ >nilai $\alpha=0,05$ ). Nilai $O R$ untuk pola makan sumber tiosianat dengan kejadian GAKY sebesar 2,28, hal ini menunjukkan bahwa subjek yang memiliki pola makan sumber tiosianat tinggi mempunyai peluang menderita GAKY 2,28 kali dibandingkan dengan subjek yang tidak menderita GAKY.

\section{Hubungan lingkungan (plumbum air) dengan status GAKY}

Dari 27 subjek yang diambil sampel air didapatkan bahwa subjek yang menderita GAKY dengan kadar $\mathrm{Pb}$ memenuhi syarat sebanyak 2 orang $(7,4 \%)$ serta subjek yang menderita GAKY dengan kadar $\mathrm{Pb}$ tidak memenuhi syarat sebanyak 25 orang (92,6\%). Selengkapnya tersaji pada Tabel 9.

Hasil uji Fisher's exact menunjukkan tidak terdapat hubungan yang signifikan antara kadar plumbum air dengan kejadian GAKY (nilai $p>$ nilai $\alpha=0,05$ ).

Tabel 9. Hubungan kadar plumbum air dengan status GAKY

\begin{tabular}{|c|c|c|c|c|c|c|c|}
\hline \multirow{3}{*}{ Kadar Pb } & \multicolumn{4}{|c|}{ Status GAKY } & \multirow{2}{*}{\multicolumn{2}{|c|}{ Jumlah }} & \multirow{3}{*}{ p } \\
\hline & \multicolumn{2}{|c|}{ GAKY } & \multicolumn{2}{|c|}{$\begin{array}{l}\text { Tidak } \\
\text { GAKY }\end{array}$} & & & \\
\hline & $\mathbf{n}$ & $\%$ & $\mathbf{n}$ & $\%$ & $\mathbf{n}$ & $\%$ & \\
\hline $\begin{array}{l}\text { Memenuhi Syarat } \\
(\leq 0,01 \mathrm{mg} / \mathrm{L})\end{array}$ & 2 & 7,4 & 0 & 0 & 2 & 7,4 & 1,000 \\
\hline $\begin{array}{l}\text { Tidak Memenuhi } \\
\text { Syarat }(>0,01 \\
\mathrm{mg} / \mathrm{L})\end{array}$ & 20 & 88,9 & 5 & 3,7 & 25 & 92,6 & \\
\hline Jumlah & 22 & 96,3 & 5 & 3,7 & 27 & 100 & \\
\hline
\end{tabular}

\section{Hubungan kadar hemoglobin dengan status GAKY}

Berdasarkan Tabel 10, data subjek yang mempunyai kadar hemoglobin normal dan menderita GAKY sebesar 39 subjek $(42,4 \%)$ dan subjek yang mempunyai kadar hemoglobin rendah dan tidak menderita GAKY sebesar 5 subjek (5,4\%). Selengkapnya tersaji pada Tabel 10.

Tabel 10. Hubungan kadar hemoglobin dengan status

$$
\text { GAKY }
$$

\begin{tabular}{|c|c|c|c|c|c|c|c|c|}
\hline \multirow{3}{*}{ Kadar Hb } & \multicolumn{4}{|c|}{ Status GAKY } & \multirow{2}{*}{\multicolumn{2}{|c|}{ Jumlah }} & \multirow{3}{*}{ OR } & \multirow{3}{*}{ p } \\
\hline & \multicolumn{2}{|c|}{ GAKY } & \multicolumn{2}{|c|}{$\begin{array}{l}\text { Tidak } \\
\text { GAKY }\end{array}$} & & & & \\
\hline & $\mathbf{n}$ & $\%$ & $n$ & $\%$ & $n$ & $\%$ & & \\
\hline $\begin{array}{l}\text { Tidak Anemia } \\
(\mathrm{Hb} \geq 12 \mathrm{gr} / \mathrm{dl})\end{array}$ & 39 & 42,4 & 26 & 28,2 & 65 & 70,6 & \multirow{3}{*}{2,933} & \multirow{3}{*}{0,038} \\
\hline $\begin{array}{l}\text { Anemia } \\
(\mathrm{Hb}<12 \mathrm{gr} / \mathrm{dl})\end{array}$ & 22 & 23,9 & 5 & 5,4 & 27 & 29,4 & & \\
\hline Jumlah & 61 & 66,3 & 31 & 33,6 & 92 & 100 & & \\
\hline
\end{tabular}

Hasil uji Fisher's exact menunjukkan terdapat hubungan yang signifikan antara kadar hemoglobin rendah dengan kejadian GAKY (nilai $p>$ nilai $\alpha=0,05$ ). Nilai Odds Ratio (OR) untuk kadar hemoglobin dengan status GAKY sebesar 2,933 hal ini menunjukkan bahwa subjek yang memiliki kadar hemoglobin $<12 \mathrm{gr} / \mathrm{dl}$ (anemia) mempunyai peluang menderita GAKY 2,9 kali dibandingkan dengan subjek yang tidak menderita GAKY.

\section{Analisis multivariat}

Pada Tabel 11 menunjukkan bahwa dari hasil analisis logistik regresi pemodelan awal maka dapat dikatakan 
bahwa ada hubungan yang signifikan antara pola makan asupan protein dan asupan yodium dengan kejadian GAKY. Hasil analisis multivariat hubungan pola makan dengan status GAKY dapat dilihat pada tabel berikut. sel kapiler kemudian ditangkap oleh thyroid binding protein (TBP). Pada keadaan protein menurun maka akan menyebabkan kadar hormon total akan menurun, penurunan hormon dari kelenjar tiroid (terutama $\mathrm{T}_{4}$ ) akan

Tabel 11. Hasil analisis logistik regresi model awal antar variabel

\begin{tabular}{|c|c|c|c|c|}
\hline \multirow{2}{*}{ Variabel } & \multirow{2}{*}{ Sig } & \multirow{2}{*}{$\operatorname{Exp}(B)$} & \multicolumn{2}{|c|}{$95 \% \mathrm{Cl}$} \\
\hline & & & Low & Upp \\
\hline Asupan protein dengan status GAKY & 0,000 & 24,440 & 5,813 & 102,758 \\
\hline Asupan besi dengan status GAKY & 0,923 & 0,895 & 0,094 & 8,497 \\
\hline Asupan zink dengan status GAKY & 0,851 & 0,821 & 0,105 & 6,394 \\
\hline Asupan yodium dengan status GAKY & 0,016 & 23,309 & 1,786 & 304,229 \\
\hline Asupan tiosianat dengan status GAKY & 0,984 & 0,986 & 0,263 & 3,705 \\
\hline Kadar hemoglobin dengan status GAKY & 0,057 & 4,235 & 0,957 & 18,750 \\
\hline
\end{tabular}

Untuk melihat besar hubungan antara pola makan asupan protein dengan status GAKY (nilai OR=24,440 dengan $p<0,05)$, asupan yodium dengan status GAKY (nilai $O R=23,309$ dengan $p<0,05$ ) artinya ada hubungan yang kuat antara kedua variabel. Untuk melihat asupan mana yang mempunyai hubungan paling besar di antara kedua asupan ini, maka dilakukan analisis logistik regresi pemodelan terakhir seperti yang tersaji pada Tabel 12.

Tabel 12. Hasil analisis logistik regresi model akhir

\begin{tabular}{lcccc}
\hline \multicolumn{1}{c}{ Variabel } & $\mathbf{p}$ & $\mathbf{E x p}(\mathbf{B})$ & \multicolumn{2}{c}{$\mathbf{9 5 \%} \mathbf{~ C l}$} \\
\hline $\begin{array}{l}\text { Asupan Protein } \\
\text { dengan Status GAKY }\end{array}$ & 0,000 & 22,810 & 6,244 & 83,330 \\
$\begin{array}{l}\text { Asupan Yodium } \\
\text { dengan Status GAKY }\end{array}$ & 0,017 & 14,685 & 1,603 & 134,492 \\
\hline
\end{tabular}

Pada Tabel 12 nampak bahwa ternyata di antara kedua asupan di atas yang mempunyai hubungan paling kuat terhadap kejadian GAKY anak sekolah di pinggiran pantai Kota Palu adalah pola makan dalam hal ini adalah asupan protein (nilai $O R=22,810$ dengan $p<0,05$ ).

\section{BAHASAN}

\section{Hubungan pola makan dengan status GAKY}

Penelitian di daerah endemis GAKY di pinggiran Pantai Polmas Sulawesi Selatan membuktikan bahwa tidak ada korelasi kuat antara keadaan geografis yang memiliki garis pantai dengan suplai ikan yang cukup akan terhindar dari kasus gondok. Persoalan yang muncul adalah bukan pada sumber yodium yang defisit tetapi pada konsumsi protein yang rendah, seperti halnya pada penelitian ini di mana asupan protein kurang dibandingkan kebutuhan asupan AKG individu (13).

Protein berfungsi sebagai Thyroid Binding Protein, asupan protein mempengaruhi kadar protein dalam serum. Pengeluaran hormon tiroid dari kelenjar tiroid karena pengaruh TSH melalui membran basalis, penetrasi menyebabkan hambatan umpan balik pada kelenjar hipofise dalam memproduksi TSH sehingga memacu kelenjar tiroid untuk meningkatkan fungsinya dalam upaya mencukupi kebutuhan hormon dari kelenjar tiroid (14). Peranan protein diduga dapat menetralisasi pengaruh tiosianat pada proses organifikasi dalam kelenjar gondok (15).

Rata-rata asupan protein subjek masih di bawah angka kecukupan gizi apabila dibandingkan dengan angka kecukupan gizi (AKG) yang dianjurkan tahun 2004. Hal ini disebabkan karena faktor ekonomi subjek yang sebagian besar orang tuanya berpendidikan SLTP dan bekerja sebagai nelayan yang hasilnya $80 \%$ dijual, juga kebiasaan makan penduduk dengan porsi nasi yang lebih banyak dan lauk sebagai sumber protein yang porsinya sangat sedikit bahkan hanya sekedar penghantar nasi. Keadaan ini diperparah lagi dengan budaya makan penduduk yang lebih mendahulukan orang tua daripada anak-anak.

Kecukupan protein di daerah endemis gondok sangat menguntungkan dengan perannya menurunkan prevalensi goiter, apabila asupan protein tidak mencukupi maka hormon tiroid tidak mampu membentuk tiroglobulin. Hasil analisis pada penelitian ini menyimpulkan bahwa terutama pada anak-anak di lokasi endemis gondok harus diantisipasi kecukupan proteinnya (16).

Berdasarkan Tabel 12 terlihat bahwa hasil uji statistik menunjukkan ada hubungan signifikan antara yodium dengan kejadian GAKY ( $p=0,017)$. Nilai Odds Ratio $(\mathrm{OR}=14,6)$, yang artinya bahwa asupan yodium mempunyai pengaruh sebesar 25,4 kali pada kejadian GAKY. Hal ini sesuai dengan hasil penelitian yang menemukan bahwa tingkat kecukupan yodium merupakan prediktor kuat terjadinya gondok di Jawa Barat dan di Maluku walaupun masyarakatnya sering mengkonsumsi ikan dan makanan laut lainnya lebih dari 1 kali sehari ternyata mengalami defisiensi yodium yang diduga oleh karena terjadi penurunan kandungan yodium pada ikan dan makanan laut lainnya $(13,14)$.

Pada masyarakat pesisir pantai di Kabupaten Maluku, salah satu pemicu timbulnya permasalahan GAKY adalah 
terbentuknya pola konsumsi yang keliru yaitu kebiasaan masyarakat yang tidak menggunakan garam beryodium dan cara pengolahan makanan atau pencampuran bumbu dengan jeruk nipis, belimbing wuluh dan cuka sebelum makanan itu diolah di mana hal ini dapat menghambat absorpsi dan metabolisme yodium dalam tubuh (17).

Pada penelitian ini dari wawancara dietary history pada subjek juga didapatkan kebiasaan mengolah ikan sebelum dimasak selalu diberi perasan jeruk nipis atau asam jawa dan cara pengolahan ikan yang selalu direbus (palumara), juga dari hasil recall 24 jam didapatkan bahwa ternyata asupan zat gizi responden masih kurang dari angka kecukupan yang dianjurkan.

Dual Fortified Salt yang berisi garam beryodium dan zat besi dalam bentuk kapsul merupakan strategi fortifikasi yang efektif pada anak sekolah di Maroko, yang mana merupakan daerah prevalensi GAKY dan anemia defisiensi besi cukup tinggi (18).

Pada Tabel 8 terlihat hasil uji statistik tidak terdapat hubungan yang signifikan antara asupan goitrogenik dengan kejadian GAKY ( $p>0,05)$, tetapi secara praktis/ klinis pada penelitian ini kemungkinan besar ada pengaruh goitrogenik dengan kejadian GAKY pada anak sekolah di pinggiran pantai. Hal ini dapat terlihat pada Tabel 5, di mana rata-rata asupan tiosianat subjek dalam batas marginal (9,8 mg/hari) dibandingkan dengan asupan tiosianat yang ditentukan oleh FAO/WHO (1994) dan juga hasil wawancara bahwa subjek sering mengkonsumsi ikan asin (85,8\%). Sesuai hasil pemeriksaan Balai POM Provinsi Sulawesi Tengah pada bulan September 2007 ternyata $72 \%$ ikan asin yang beredar dan dikonsumsi oleh masyarakat di Sulawesi Tengah mengandung senyawa pestisida organofosfat.

Hasil penelitian di daerah pantai Kabupaten Banggai menemukan bahwa adanya faktor-faktor konsumsi umbiumbian yang mengandung goitrogen ternyata berperan memperberat keadaan status gangguan akibat kekurangan yodium (19). Juga penelitian pada anak sekolah di Kabupaten Dairi, di mana hasil penelitiannya bahwa ada hubungan antara status pestisida (kadar kolinesterase) dengan status gangguan akibat kekurangan yodium (kadar EYU) (20).

\section{Hubungan lingkungan (plumbum air) dengan status GAKY}

Pada Tabel 9, terlihat bahwa dari 27 subjek (sampel air minum secara acak) sebagian besar subjek penderita GAKY dengan nilai plumbum $(\mathrm{Pb})$ tidak memenuhi syarat. Hasil uji statistik tidak terdapat hubungan yang signifikan terhadap kejadian GAKY dengan nilai $(p=0,658)$. Namun secara praktis/klinis ada hubungan, karena lokasi penelitian berada pada kawasan industri, sehingga kadar plumbum pada sumber air yang dikonsumsi sebagian besar tidak memenuhi syarat. Hasil penelitian ini bertentangan dengan penelitian di Malang tahun 2002 yang menyatakan bahwa timbulnya penyakit gondok di daerah pantai bukan disebabkan karena rendahnya konsumsi yodium, akan tetapi sangatlah besar karena intoksikasi plumbum (21).

Penelitian di Kabupaten Madiun didapatkan bahwa hasil uji statistik menunjukkan tidak ada hubungan plumbum dengan kejadian gondok pada daerah gondok endemik dan nonendemik walaupun kadar plumbum di tanah lebih dari normal (>5-25 ppm) (22).

Menurut De Groot pada individu yang kekurangan selenium dapat menyebabkan tubuh lebih rentan terhadap masuknya unsur timbal $(\mathrm{Pb})$. Akibat kelebihan unsur $\mathrm{Pb}$ ini akan membentuk ikatan yang sangat kuat dengan unsur yodium di dalam tubuh sehingga yodium tidak dapat digunakan untuk biosintesis hormon dari kelenjar tiroid. Kekurangan unsur selenium dapat menyebabkan tubuh menjadi lebih rentan terhadap masuknya unsur timbal $(\mathrm{Pb})$ dan rubidium ( $R d$ ) serta logam berat lainnya. Bila asupan timbal dan rubidium berlebihan dapat menyebabkan terjadinya pembesaran kelenjar tiroid (23).

\section{Hubungan kadar hemoglobin dengan status GAKY}

Berdasarkan Tabel 10 terlihat bahwa hasil uji statistik antara kejadian GAKY dengan kadar hemoglobin, menghasilkan nilai $p=0,038(p<0,05)$, ini berarti bahwa ada hubungan yang signifikan antara kejadian GAKY dan anemia. Nilai odds ratio $(\mathrm{OR}=2,933)$ yang artinya bahwa subjek yang mempunyai kadar hemoglobin kurang dari $12 \mathrm{gr} / \mathrm{dl}$ (anemia) mempunyai risiko 2,9 kali menderita GAKY.

Di negara berkembang, banyak anak usia sekolah berisiko tinggi mengalami pembesaran kelenjar tiroid dan menderita anemia defisiensi besi (24). Defisiensi zat besi akan menurunkan aktivitas enzym tiroid perioksidase (TPO), yang mana tiroid perioksidase merupakan enzym yang mengandung heme dan berfungsi sebagai katalisator dalam sintesis hormon tiroid. Di samping itu defisiensi besi juga dapat mempengaruhi efek suplementasi yodium di daerah endemik GAKY.

Hasil penelitian ini berbeda dengan hasil penelitian di Dairi, Sumatra Selatan yang menyimpulkan bahwa tidak terdapat hubungan yang signifikan antara status anemia dengan status GAKY pada anak SD $(p>0,05)(20)$.

Anemia zat besi dipengaruhi oleh multifaktor, tidak hanya karena asupan zat besi yang kurang, namun juga dipengaruhi oleh asupan zat gizi lain. Di daerah endemik GAKY, kemungkinan prevalensi anemia ibu hamil lebih tinggi daripada daerah nonendemik GAKY, karena masyarakat yang tinggal di daerah ini cenderung defisiensi yodium (24). Yodium merupakan salah satu zat gizi yang berperan dalam metabolisme pembentukan hemoglobin.

Penelitian di Pantai Gading menunjukkan bahwa suplementasi zat besi dapat meningkatkan keberhasilan 
penggunaan garam beryodium pada anak yang menderita gondok dan defisiensi zat besi. Ukuran kelenjar tiroid setelah 20 minggu intervensi pada kelompok yang diberi garam beryodium dan zat besi secara bersama-sama mengalami pengecilan hampir 2 kali lipat dibandingkan kelompok yang hanya diberi garam beryodium saja. Penelitian ini menyimpulkan suplementasi zat besi meningkatkan pengaruh garam beryodium dalam penanggulangan GAKY (25).

\section{KESIMPULAN DAN SARAN}

Ada hubungan faktor pola makan (asupan protein, dan yodium) dengan kejadian gangguan akibat kekurangan yodium pada anak sekolah di pinggiran pantai Kota Palu. Tidak ada hubungan faktor lingkungan (Plumbum) dengan kejadian gangguan akibat kekurangan yodium derajat 1 dan 2 pada anak sekolah di pinggiran pantai Kota Palu. Ada hubungan faktor hemoglobin anak terhadap kejadian gangguan akibat kekurangan yodium pada anak sekolah di pinggiran pantai Kota Palu.

Berdasarkan hasil penelitian ditemukan bahwa asupan protein dan yodium pada subjek masih sangat rendah/ kurang dari angka kecukupan gizi. Untuk itu saran yang diberikan adalah: (1) puskesmas mengadakan penyuluhan tentang pentingnya konsumsi makanan dengan pola menu gizi seimbang, cara pengolahan makanan, promosi tentang garam beryodium dan kunjungan rutin ke sekolah untuk skrining GAKY secara sederhana (1 kali/tahun), (2) Dinas Kesehatan mengadakan sosialisasi dan advokasi ke Pemda dan dinas terkait tentang GAKY dan cara penanggulangannya serta mengadakan advokasi kepada pengusaha garam untuk melaksanakan yodisasi garam sebelum didistribusikan kepada konsumen; serta (3) dari segi pendidikan mengadakan penelitian lanjut tentang GAKY dengan metode dan variabel lain yang belum diteliti, seperti pemeriksaan thyroglobulin dan pemeriksaan fungsi kognitif serta prestasi belajar.

\section{UCAPAN TERIMA KASIH}

Pada kesempatan ini tak lupa penulis menyampaikan ucapan terima kasih kepada seluruh anak SD di Kecamatan Palu Utara yang telah bersedia menjadi sampel dalam penelitian dan semua pihak yang turut membantu hingga selesainya penelitian ini.

\section{RUJUKAN}

1. Departemen Kesehatan RI. Penanggulangan Gangguan Akibat Kurang Yodium (GAKY) di Indonesia. Jakarta: Direktorat Bina Gizi Masyarakat Departemen Kesehatan RI; 2001.
2. Departemen Kesehatan RI. Rencana Aksi Nasional Kesinambungan Program Penanggulangan Gangguan Akibat Kurang Yodium. Jakarta:Tim Penanggulangan GAKY Pusat; 2005.

3. Hetzel SB, Clugston AG. Iodine in Modern Nutrition in Health and Disease. Ninth Edition. Baltimore: Lippincott Williams \& Wilkins 1999. pp 253-64.

4. Djokomoeljanto R. Evaluasi Masalah Gangguan Akibat Kurang Yodium (GAKY) Di Indonesia. Jurnal GAKY Indonesia 2002; 3 (1):31-9.

5. Soeharyo H, Margawati A, Setiawan H, Djokomoelyanto. Aspek Sosial Kultur Pada Program Penanggulangan GAKY, Jurnal GAKY Indonesia 2002; 1(1):41-6.

6. WHO, UNICEF, ICCIDD. Assesment of lodine Deficiency Disorders and Monitoring their Elemination, Second edition. U S A: WHO; 2001.

7. Greenspan SF. Endokrinologi Dasar dan Klinik. Wijaya, C.,Maulany, R., Samsudin, S. 2000 (Alih Bahasa). Edisi 4, EGC: Jakarta; 2000.

8. Widodo SU. Membangun Survailens GAKY di Tingkat Kabupaten /Kota. Magelang: Balai Pengobatan GAKY; 2004.

9. Departemen Kesehatan RI. Rencana Aksi Nasional Kesinambungan Program Penanggulangan Gangguan Akibat Kurang Yodium. Tim Penanggulangan GAKY Pusat: Jakarta; 2005.

10. Dinkes Propinsi Sulawesi Tengah. Profil Kesehatan Sulawesi Tengah: Dinkes Sulawesi Tengah; 2005.

11. Dinkes Kota Palu. Profil Kesehatan Kota Palu: Dinkes Kota Palu; 2005.

12. Lemeshow S, David WH, Janelle K. Sample Size Determination in Health Studies A Practical Manual. Geneva: WHO; 1997.

13. Sirajuddin, Rauf S, Salim A. Kadar lodium Urine Dan Pembesaran Kelenjar Gondok Anak Sekolah Dasar Di Daerah Pantai Polmas. Makassar: Media Pangan Gizi 2007; 4(2)

14. Djokomoeljanto R. Evaluasi Masalah Gangguan Akibat Kurang Yodium (GAKY) Di Indonesia. Jurnal GAKY Indonesia.Vol 3 No 1 2002; pp.31-9.

15. Thaha RA, Dachlan, MD, Jafar N. Analisis Faktor Risiko Coastal Goiter, Jurnal GAKY Indonesia 2002;1(1): 9-17.

16. Mayes PA. Pencernaan dan Absorpsi Dalam Biokimia Harper, Hartono, A. (Alih Bahasa). EGC: Jakarta; 2003.

17. Picauly I. Suatu Tinjauan Ontologi dan Aksiologi lodium dalam tubuh serta Gambaran GAKI Masyarakat Endemik GAKI Pesisir Pantai Kabupaten Maluku. Iodium dan Gangguan Akibat Kekurangan Iodium: Pasca Sarjana Institut Pertanian Bogor; 2002.

18. Zimmermann MB et al. Dual Fortification of Salt with lodine and Micronized Ferric Pyrophosphate: 
a randomized, double-blind,controlled trial. American Journal Clinical Nutrition 2003; 80 : 952-9.

19. Subekti I. Faktor-Faktor yang Berpengaruh Terhadap Timbulnya Gangguan Akibat Kekurangan Yodium di Daerah Pantai. JKPKBPPK. [serial online] 2002 [cited 2007 Jul 26].

20. Maryanes, Lestariana W, Widodo SU. Hubungan Antara Status Gangguan Akibat Kekurangan Yodium (GAKY) Anak SD Pada Daerah Endemik GAKY Kabupaten Dairi. Jurnal Gizi Klinik Indonesia 2007; 4 (3): 123.

21. Adriani M, Wirjatmadi B, Gunanti RI. (Identifikasi Gondok Di Daerah Pantai : Suatu Gangguan Akibat Kekurangan Yodium: Jurnal GAKY Indonesia Vol 3 No 1 2002; pp.1730.

22. Esvanti M. Hubungan Kandungan Yodium, Selenium, Seng, Nitrat dan Timah Hitam Terhadap Kejadian Gondok Di Daerah Endemik Gondok dan Non Endemik Gondok Di Kabupaten Madiun. [Serial online] 2004 [cited 2008 May 9]. Available from: jiptunair-gdl-s2-2004-esvantimir-1221Airlangga Univesity Library-GDL 4.0.

23. Lagahu F, Trisnowo, JE, Iswani S, Djokowidodo. Unsur Kelumit Dalam Bahan Lingkungan Hidup dan Tubuh
Manusia Pada Penduduk Daerah GAKY di Kabupaten Magelang Dalam Kumpulan Naskah Lengkap Simposium GAKY, Kongres Nasional III Perkumpulan Endokrinologi Indonesia (PERKENI). Semarang: Badan Penerbit Universitas Diponegoro; 1993

24. Zimmermann MB, Adou P, Zeder C, Torresani T, Hurrel RF. Persistence of Goiter Despite Oral lodine Supplementation in Goitrous Children with Iron Deficiency Anemia in the Cote d'Ivoire. Am J Clin Nutr 2000; 71:88-93.

25. Widagdo D, Latifah L, Setyani A. Peranan Konsumsi Tablet Fe inhibitor dan Infeksi Parasit Terhadap Kejadian Anemia pada ibu hamil di daerah Endemis GAKY Kabupaten Magelang. Prosiding Temu IImiah Kongres XIII PERSAGI. Bali: Persatuan Ahli Gizi Indonesia; 2004.

26. Hess, Sonya Y, Zimmermann BM, Arnold M, Langhans W, Hurrel FR. Iron Deficiency Anemia Reduces Thyroid Peroxidase Activity in Rats. The American Society for Nutritional Sciences J.Nutr B2002; 132: 1951-5. 